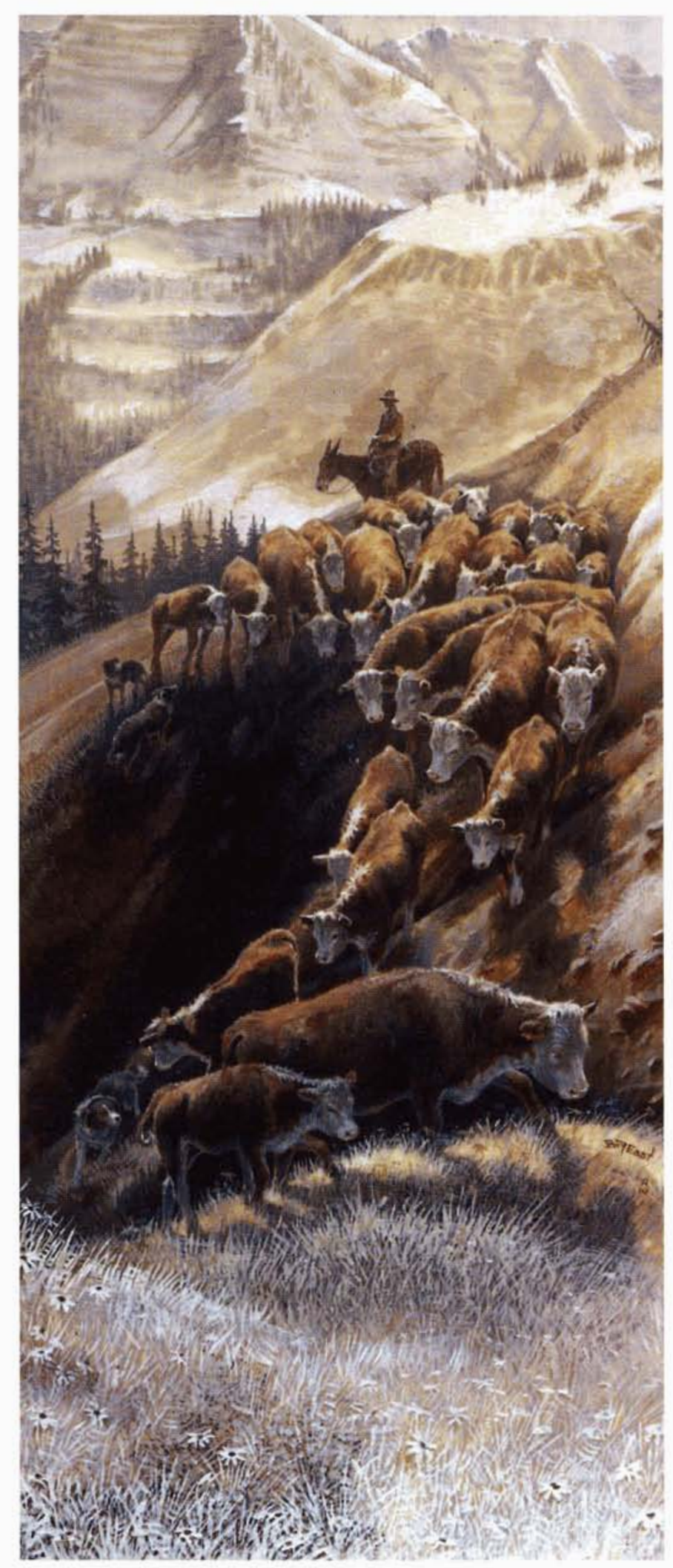

A self portrait: Artist and Range Rider Barbara East finds inspiration in the land she cares for and the pictures she paints.

\section{The Art of Range Riding: A Coat of Many Colors}

\section{By Barbara East, as told to Polly Oberosler}

Barbara approached me to help organize her incredible collection of thoughts, philosophies and experiences that she had scripted over the years of range manage-

ment. Seen through her eyes as a range rider, range management takes on a whole new artistic and creative dimension much as her artwork depicts visions of true western life seldom seen.

What follows is a collective effort to represent her take on range management that culminates from years as a range rider.

\section{- Polly Oberosler}

I have spent most of my life creating paintings surrounding the life that I live as a range rider. The study of range management for me has been a 32 year course from the back of a mule. The intricacies of balancing the management of cattle on the range with wants and desires of the rancher, the agencies and the public are only the beginning for a range rider in these times of fast paced, computer generated images of what should be.

I look to the intimacy developed between the land and myself, and the detailed observation I have been allowed as a range rider to guide me in my stewardship of land and preservation of the nearly lost art of herding.

I was twenty-three years old when I first contracted the care of 1,500 head of cattle on 54,000 acres of high country range on several adjoining United States Forest Service grazing allotments. To have been delegated so much responsibility was an honor. The fact that an area so beautiful had been entrusted to my care was at the heart of my every effort to preserve it.

It was a time when the range bosses gave you a map of the permitted area, told you to hide the cows from the Forest Service, then bid farewell with, "see you in the fall." We grazed under a very simple system: take half, leave half, keep them away from the creeks and the camping spots.

The bulk of my range riding has been spent taking care of allotments close to a resort community in Colorado with a strong emphasis on recreation and environmental concerns. Most of my charge was in sensitive and highly visible areas where the Forest Plan Management prescription was recre- 
ation, wilderness and winter wildlife habitat with grazing holding a lowly place in the ranking of priority. It was imperative for me, and my kind, to think of responsibility not only for the livestock, but the land on which they grazed.

For 26 years I returned to those mountains as a contract range rider where experience demanded my thinking evolve into what I focus on today as a resource manager, rather than simply a rider. I learned through thoughtful observation the things only someone with daily contact can hope to ascertain, starting with our impact on the very land that this age-old method of stock growing depends on.

As a range rider, I am out there everyday of the week moving the cattle as they harvest an area of forage. The prescription for the timely movement of stock depends on the complex interaction between the terrain, season, class and behavioral characteristics of cattle, water availability and the stage of the various plant species. I am keeping the day-to-daywatch on the stock and their whereabouts and generally being the eyes for the permit holder, which is an invaluable asset for them. As well, I find myself a defacto ambassador among the other land users.

In my eyes, it is imperative that someone is out there every day to insure that the land is taken care of as that is the most important part of the quotient, and the only way that the land maintains its ability to sustain cattle in a productive way.

Trial and error taught me. Fear of error motivated me to cultivate my skills of land management lest we would loose the grazing permit on the forest. Born in me from this is a fierce dedication and a powerful sense of responsibility to the land which we must not lose sight of.

\section{\#\#\#}

The following questions result from thoughts that kept rising to the surface while talking to Barbara during the course of writing this article. They are issues that seemed best addressed in a question and answer format in order to draw more completely on her hours-in-the-saddle philosophy of wild land grazing, stemming from her years of experience.

Q: You are reluctant to call yourself an expert or authority on range management even though you have been a professional range rider for $\mathbf{3 2}$ years. Why?

A: I feel that range riding is an area where no one can be an authority. Every range, rancher, and herd of cattle vastly differ. I can only draw from areas that I have experienced over time. I am a very small dot in a vast area of scenery and philosophy. We are still writing the book on the dos and don'ts of range management in this day and age, and for differing areas of the country. It's an integrated complex system rooted in individuality that is trying to survive in a society that's skeptical of uniqueness and individualism.

Q: Would you describe what a range rider is to you and what daily life brings to you as a range rider?

A: A range rider is a herder with a degree in the science of "Jack of all trades" when it comes to cattle and grass, and a minor in public relations. A large part of being a successful rider is having the ability to recognize and develop systems that work with whats naturally out there, and having the livestock handling skills and the dedication to keep the cattle moving within those plans.

Daily life is the mundane spiked with unpredictable variety. A rider will repeat some jobs such as putting cattle out of the riparian areas many times, and sometimes many times in a given day.

Variety is a mixed bag of happen stance from dealing with your five mule pack string meeting a llama on "their" trail, to finding a gate open and

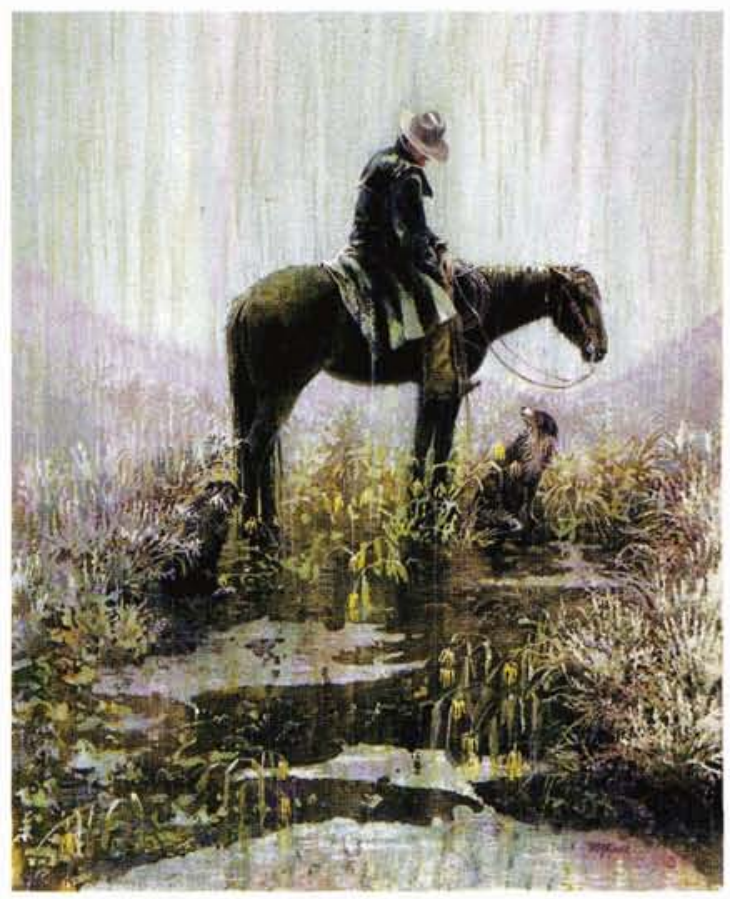

A Day in the Life: Cold, wet, muddy and slick, or hot, dusty, lightning and fires. Range riding can be monotonous, often dangeros and no amount of knowledge makes it less work. 


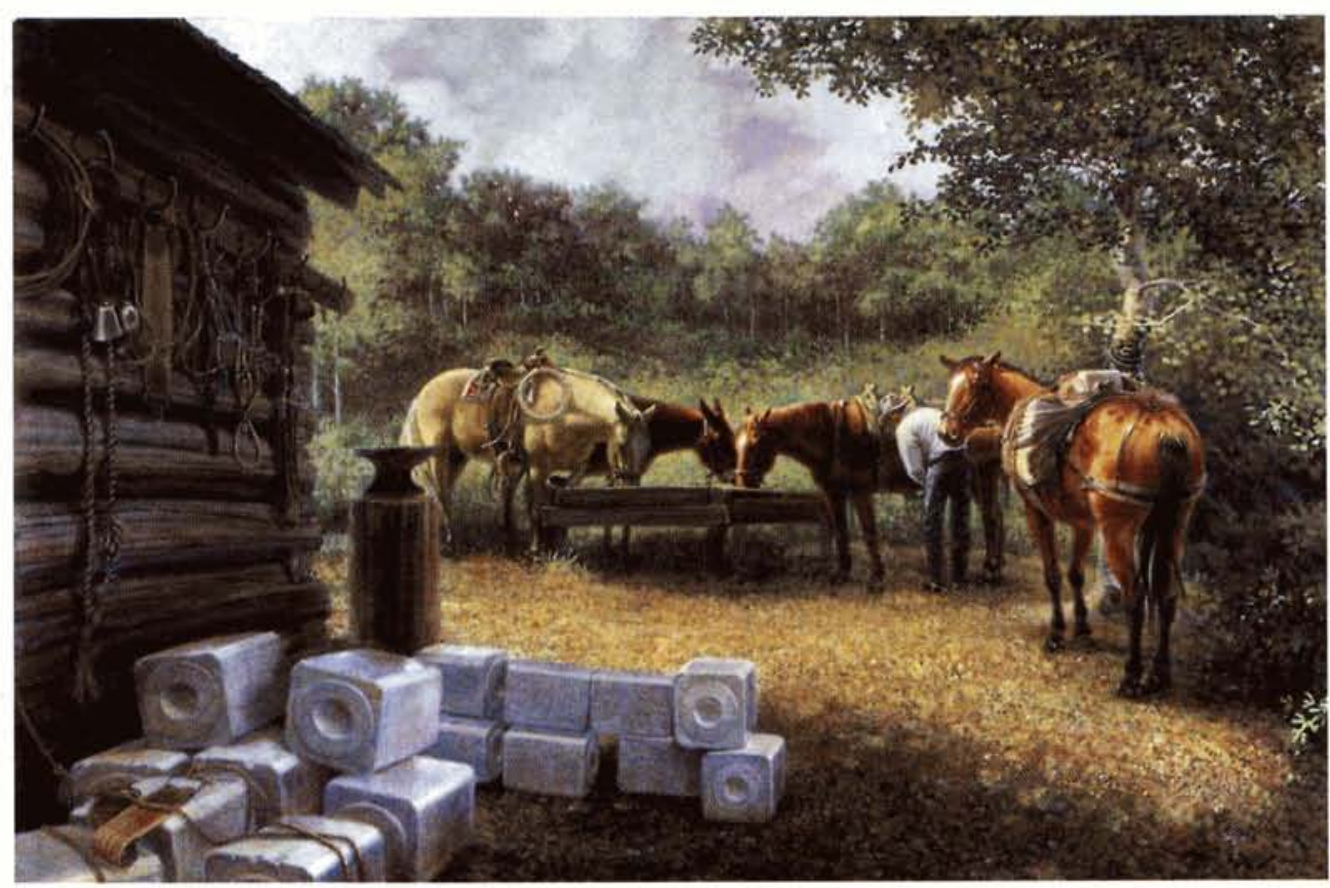

A Range Rider's Camp: Fifty lb salt blocks are often split in half with an ax for better distribution. They are then packed out $200 \mathrm{lbs}$. per pack animal, into areas away from water sources that cattle may otherwise not utilize.

that you've acquired your neighbors cows, to being involved in the rescue of a hiker. The mundane is more to the essence of it; the daily movement of cattle, fence work, trail cleaning, the monitoring of range and water, keeping daily records, doctoring an occasional sick animal, and the twice daily chore of caring for your horses and dogs.

\section{Q: Why aren't there more range riders out} there?

A: Basic economics are generally the reason why there are not more of us out there. It is seasonal income with year round expenses. It's a job with a questionable future that in many ways doesn't lend itself to family life; living conditions are less than luxurious.

Also many riders have the idea that they are going out there to train their horses or to look like a cowboy only to discover the job is hugely time consuming. Once they get out on the ground, they find out quickly that range riding is not all what they thought it was, and few of them realize exactly what it is about: the land. It has little to do with "cowboying" and a lot to do about cows. You can be just as effective riding a jackass that you can not turn in 40 acres as you can using a $\$ 30,000$ cutting horse. One might be more effective with the ass!

\section{Q: Is there a school for range riders?}

A: Yes. The land is the school and the course is called Trial and Error 101 with major emphasis in observation. The best teacher steps in when you gather the cows. It is like an overview on a big screen: where you could have placed salt blocks to encourage more grazing: identifying damaged areas that you need to work cattle away from in the future: and paying detailed attention to the land's response to the presence of cattle.

There are range tours and some great short courses in range management and monitoring that are being presented by Federal agencies and Land Grant universities.

These courses are presented in many areas for the ranchers, riders and interested public. I personally attend every one that I can, and I feel that listening to new and different viewpoints stimulates creative thinking and solutions.

\section{Q. Do all ranchers favor the concept of having} a range rider?

A: No, a great many stock growers do their own riding. However, in instances where more than one ranch is involved on a grazing allotment, or if it is a long distance from the ranch, a rider is hired as an extension of the rancher. 
Based on elements of trust the well being of a large investment is at the hands of daily decisions made by the rider. Many ranchers are reluctant to hand over the whole of their existence to someone that is perhaps not of their thinking.

It is not very hard to kill thousands of dollars worth of cattle if you drive them into a poisonous larkspur patch and let them graze. Just as costly a mistake might be allowing a large majority of the bulls to hang out with a small herd of cows. The results would be a large number of open and dry cows. No wonder the hackles come up on many ranchers with the very mention of a range rider.

Range riders who display a false knowledge base or misrepresent their abilities can have costly results for the rancher. Likewise, a rider that is doing the job well and has a workable operating plan can maximize cost effectiveness and insure long-term stability.

Q: If you were considering a range-riding job, what ingredients would you consider necessary on the permit in order to be successful?

A: Adequate water; adequate forage to number of cattle; flexible, solutions seeking personalities both on the part of the agencies and ranchers, and compatible livestock handling philosophies.

I learned the hard way that if the range looks bad and the permit holder likes it that way, and blames others for its condition, I best stay away. Sometimes riders are hired with the thought of them being an instant cure-all, which they cannot be because change comes slowly and only by making a constant effort year after year. Only by monitoring what we are doing can we affect change and in turn begin to see it.

Q: You've mentioned the "order" of cattle. Could you explain that and why it is important?

A: True range cattle are as unique as the range itself. It becomes apparent when handling them that they have as definite a social structure as people or ants. There are leaders and followers, friends and foe. They have cliques, clans and preferences.

I believe the trick in getting cattle to work the country efficiently without resource damage is to not entirely disrupt their naturalorder when moving them, and that takes time. Driving cattle up the road to a destination is different than drifting them into fresh feed.

I think of range riding as a discipline and the study of patience in a clockless workplace where the pace of a cow and the track of the sun measure

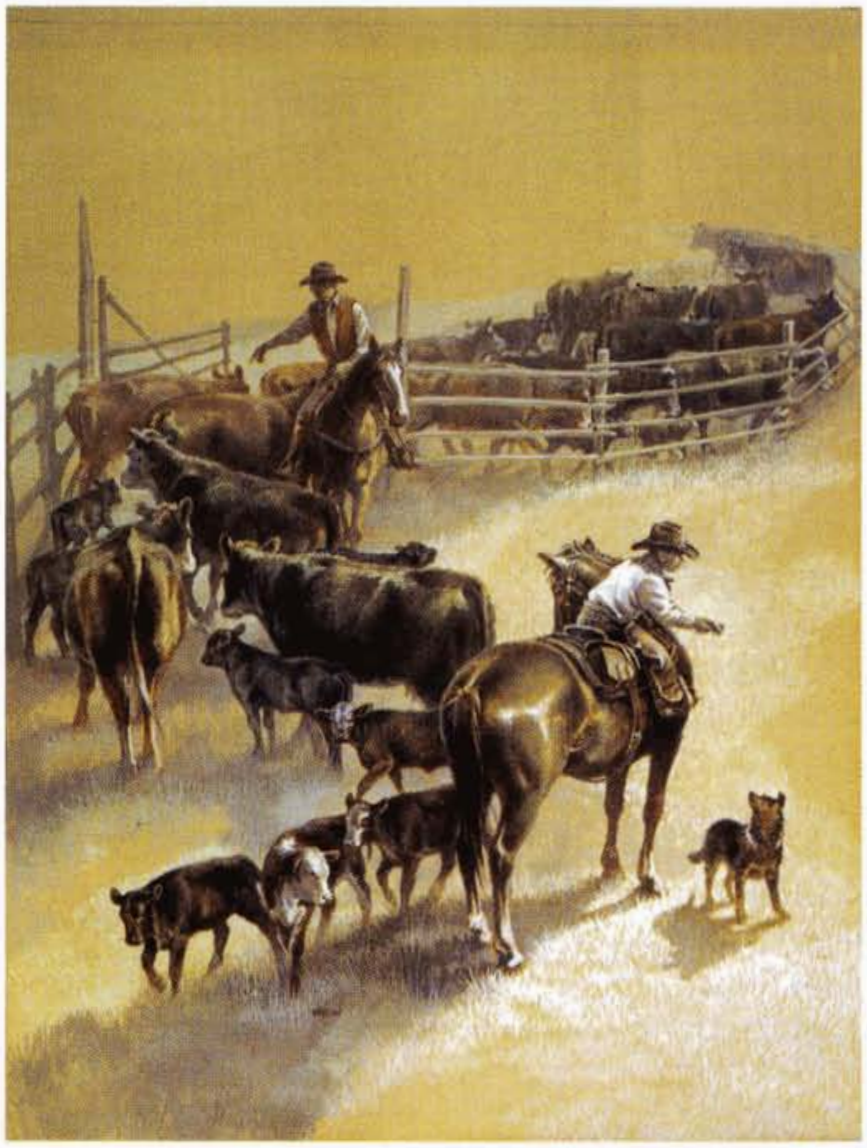

My Dogs

Stockdogs control the ebb and flow of their world with a command and balance unparalleled. Their self-esteem, sense of purpose and confidence comes from working.

the rate of time. If the cows are mad, and the herd mixed up when you arrive at your destination a greater number of them tend to go right back where you started trying to regain their order. You then will most likely trample through the same scenario the next day causing additional stress on the land and cattle.

The key to successful range utilization is training the cattle. They are trainable if they are handled consistently. Cattle are intelligent and sensitive animals. Working from that basis is the art form of true stockmanship. Skilled livestock handling is like putting the eight ball in the corner pocket of a pool table... it amounts to using the right amount of pressure from the correct angle.

Many times a rider is most effective when stopped; letting the cattle drift away in the right direction to re-establish their natural order. Recognizing that stress in handling directly affects 
pound gain and health in livestock is an immeasurable contribution where the rider can contribute greatly to the permit holder and his/her profits. I agree with Bud Williams: "The most important thing about doctoring cattle is to achieve a level of cattle handling that doesn't contribute to sickness."

When you train your cows you build a trust in those cows by consistency in handling by pressure versus release of pressure and an introduction to fresh feed as reward. Range rider Tim McGaffic said it well: "When you take time to work with your herd you are making a deposit in the bank of trust. When you need it, it is there to draw from. But when you change the rules, you lose the principal."

\section{Q: How many cattle can one rider take care of?}

A: There is no set number. Each allotment has unique characteristics. It largely depends on the nature of the country, amount of outside pressures, the class and the mindset of the cattle. It also depends on how many fences and where they are.

For many years I rode a series of smaller adjoining allotments that were managed separately. I was responsible for more than 1700 head and spread over 60,000 acres at times with very little help and few fences. I allowed the cattle to break into natural bunches of one to two hundred head; it was then easy to manipulate those bunches into specific destinations and time frames. The natural boundaries and water distribution was right for it. We had a definitive plan with 31 grazing areas on one permit alone. The primary focus was on preventing backgrazing or staying in one area too long. It worked well. I would not even attempt to take care of that many cattle if they were in one bunch.

I believe one of the most difficult challenges land managers have put in front of us as range riders is the concept of herding the cattle traveling across the land condensed in one sheep like bunch. In its purest interpretation this concept is dangerously idealistic. It sounds good, but it fosters a high instance of unrealistic expectations. Fundamentally, cattle are not like sheep in respect to their social and grazing behaviors. The concept is so rider dependant, yet it neglects to recognize that there are very few qualified range riders out there.

Steve Allen is one of six permittees doing his own range riding on the 90,000 acre West Elk Allotment in the GMUGNF where they have, for the last ten years, made huge progress in training their 11,000 head to move in one unit. "We pay riders a mini-

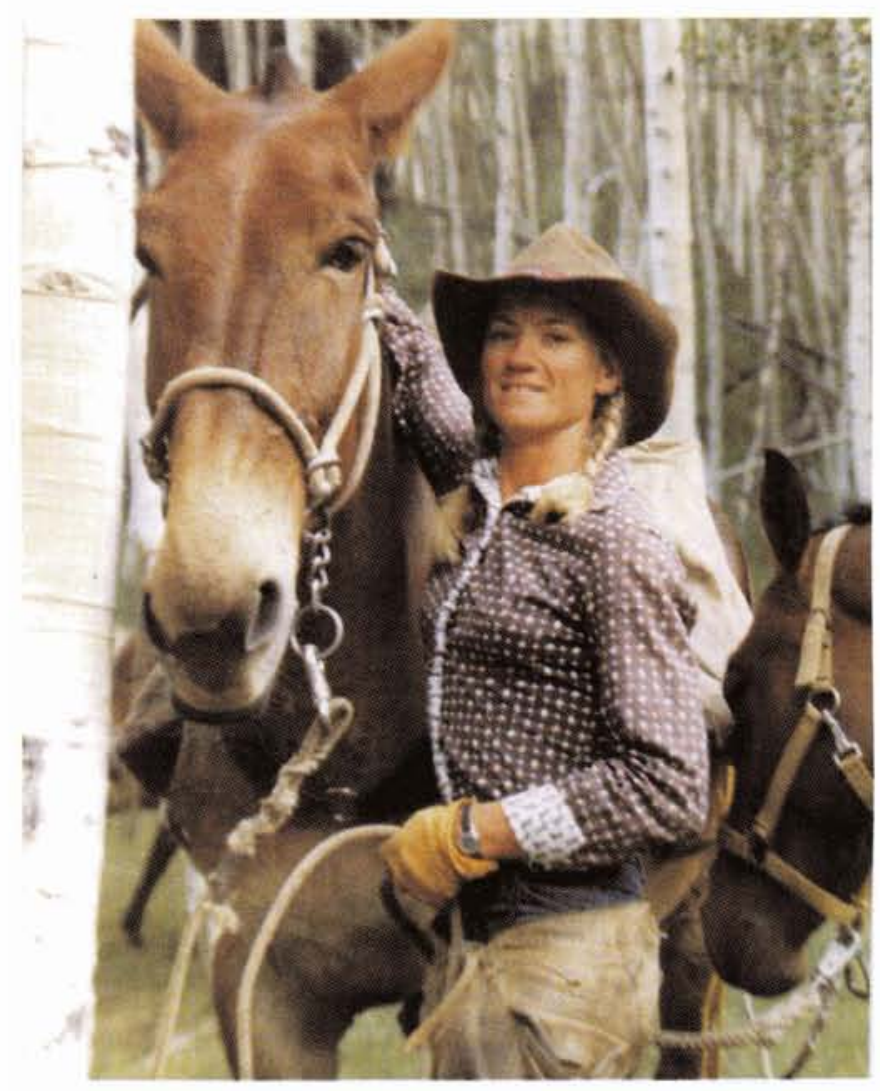

Barbara East and "Anvil" Photo by Anis Kelly.

mum wage: they're at the bottom end of the societal pay scale - yet we are asking for skill that is on the top end of accomplishments in the industry. So far even the experts have not been able to accomplish this concept as herders. We haven't figured out yet how to entirely make it work either, but we know riders are integral players. What we have been able to accomplish is that by continually drifting the cattle in a large planned grazing pattern, we do not over graze plants. But we still over rest plants. Where this concept is being done well enough for hoof action to affect the land, fences are involved; a big corral. To be successful it takes real commitment-more money, more labor, and more new thought."

There are other shining examples out there, and where close herding is being done, it is unquestionably good for the resource.

Don Sabrowski, manager of Wapiti Ranch and the 96,000-acre Spring Creek allotment on the GMUG national forests is no stranger to moving his cattle across the land in one large unit, and has been doing it for eight years with 400 pair. "This grazing system is dependent on the rider. In hiring a rider I am 
not looking for experience alone, but at the person's mindset. Their lifestyle must allow them to live with the cows and love it. Their own pride dictates the success or the failure of the job they do. They must understand what the grazing system goals are and be creative enough to adapt to each area's challenge."

Salt and water distribution are important tools to help disperse cattle within each grazing area. "The biggest key and the biggest problems are your lead cows. You have to have them to draw the herd, but they are the ones you continually must turn back to the bunch, as well as the dominant bulls and their harems. These are the reasons that a rider needs to always be diligent about riding the perimeter of the herd."

It is debatable if it is cost effective to have a full time rider with less than 500 pairs. In large country it takes the same amount of horses, almost as much equipment, and every bit as much work. The expenses alone for a rider can be as high as $\$ 4,000$ to $\$ 5,000$ a grazing season because of wintering the animals necessary for the job. Where use of trucks and trailers, and camp trailers come into the picture, the cost is greater. It is very close to being classified as a hobby. I think it is a much too important job to be classified as a hobby.

Q: "Multiple Use" is on the forefront of everyone's thinking; can the range rider play a part in ensuring that the stock grower fits into that system?

A: Yes, I represent the permitted stock grower out there all day, every day. While managing the cattle and the grass, packing salt and clearing trails, I end up helping tourists with directions, fishermen find fish, hunters find game and hikers find trails. The job is making sure that cattle grazing remains compatible with all other users. If I am doing my job, the presence of cattle should not ruin someone else's experience. Pride in sharing our ranching heritage and our area can foster a lot of public acceptance. Multiple use is about maturity and self-restraint on the part of everyone.

$Q:$ With the current trend toward organic foods, could wild land grazing get a boost by following that trend?

A: I have always been in the habit of putting myself in the cows place, and quite frankly once considered doing a comic series entitled, "Life On The Multiple Use Range" from the cow's point of view. I have envisioned them grazing, enjoying the scenery, people watching, and basically enjoying the good life, better than free-range chickens.

\section{The Economics of Range Riding}

It's probably a good thing we don't figure out how much we're making per hour. We come from a culture that tends to put a high value on accomplishment while overlooking the time it took to achieve that accomplishment.

As an independent contractor, I always looked at dollars per AUM, then at usage per month because that's what the rancher needs to know.

How much equipment one needs, and how many horses, dogs, mules, as well as the amount of use and expenses on the almost always necessary $4 \times 4$ truck, horse trailer and in some areas camp trailer, differ widely from one situation to the next. Following is a hypothetical scenario for roughly estimating a rider's expenses:

500 pairs; June 1 to Oct. $15 ; 25,000$ acre mountain allotment; 10 miles of fence, partially laydown; 10 miles of truck and trailer use per day, seasonlong. There is no cow camp, no cross fence. Permittees prefer to use mineral $(13,500 \mathrm{lbs}$. per season) rather than white salt $(4,063 \mathrm{lbs}$. per season).

I estimate I will need:

5 horses or mules $\$ 476$

average annual cost.

$\$ 2380$

4 dogs

$\$ 1312$

fencing supplies

.\$83

camp trailer utilities

$\$ 202$

gas for daily use of truck during season $\quad \$ 225$

two extra tires (one for truck/one

for stock trailer)

$\$ 140$

vehicle and trailer licenses

$\$ 70$

health insurance

$\$ 346$

TOTAL

$\$ 4758$

Note: This figures out to about $\$ 2.11 / \mathrm{cow} /$ month on 500 pairs. This does not include vet expenses for animals, or purchase and repair of equipment such as saddles or the many other miscellaneous items one finds necessary for the job.

It wasn't until I read Prepare For The Future Of Rangelands in the December, 2001 issue of "Rangelands" magazine that I thought in terms of product presentation, using the cowboy in a rather non-mechanical way of beef production that could quickly gather public acceptance by those critical of the beef industry. However, it must prove to be economical and there must be excellence in grazing management for it to become widespread reality. Given that the economics would make it feasible, I think that it would be very beneficial to the industry as a whole to look forward to organic production of 
beef as another alternative in the future. Certainly wild land grazing would get a boost since it is the most organic form of feed available.

\section{Q: What do you see as the future for range rid-} ers and for grazing on public lands?

A: The development of GPS technology with bilateral virtual fencing capabilities will someday allow multiple areas to be effectively managed by a single person. However, . . .carrying a laptop aboard my mule could come very close to killing my cowboy image. . . Or does it turn the page, leading to future demand for range riders that are technologically savvy, ecologically astute, skilled livestock handlers?

The future of grazing on public lands today is dependent on the fate of the associated private lands. As growth and development gnaw away at the open lands and grand scheme of the future, each nail pounded is a nail in the coffin of public lands grazing. Modern society, fast paced and materialistic, is the enemy of the venerable system built on a man's word and a handshake contract that many western ranchers still struggle to preserve. I believe the cattle and their ranchers belong out on the range. While these ranches may not be the most important contributors to the beef industry, as it exists today, their contributions to the esthetic and contiguous wildlife habitat value are irreplaceable.

The greatest attribute of public lands grazing lies in the preservation of the land connected or dependant on the permit. When the permit is gone, the sustainable ranch connected to it will be gone, as we know it today. Is that what this generation wants their grandchildren to inherit?

True range cattle have an uncanny ability to adapt to their home ranges, in short an inherited "rangeability" has developed over time and generations. These cattle have been conditioned and trained to live in their specific environment. It is just now being understood that cattle have an innate survival ability that is largely inherited and is definitely connected with habitats where they are born, raised and trained. People need to realize that the removal of these herds from the land is an irreversible action.

Q: Are there creative solutions out there, and what solutions would you suggest?

A: To think out of the historic "box" is something that is becoming more and more necessary, even if that box is currently working. If for no other reason than to keep from getting bored and stagnate, which is dangerously non-productive, it is a non-creative place to be. Creative thinking breaks limiting habits and creates diversity in land use patterns. It is good for the range, but sometimes hard on the public-suddenly there are cattle where there were never cattle before. It is also hard to teach a cow to think with the right side of her brain!

$$
\text { \#\#\# }
$$

It is one of life's highest callings and greatest privileges to be part of a system working on the landscape. Beyond commitment and time invested, range riding is the daily representation of your innermost beliefs about the way in which we should relate to the land.

It's the beauty of the land that first haunts you after you've gone, and then it's the lost opportunity to ever again be a working part of that landscape. They say you never really leave a place you love, some of it you take with you: the knowledge, memories, and experience, but you leave your heart behind.

A range rider is simply a tool in range management, merely a dot on the western landscape, but many dots can make a picture complete.

There will never be money to be made on the range, but life's most important lessons are out there-real wealth is knowing that nobody is watching but you. There are no short cuts or quick fixes. It is simply hard work that makes things happen.

I return to my old ' 67 camp trailer each night, often long after dark, living with a luxury of values in what some would call a below poverty existence. But I sleep well-as my old one-eyed cat listens to the mice in the wall.

About Barbara East: In addition to being a range rider, East is a Western artist. As seen in the images that accompany this article, her works include landscapes and livestock. For more information about her paintings, visit Barbaraeast.com or contact East at 202 637-B So. Broadway, Boulder, $C O$ 80305 or call at 303-494-1038.

East makes these acknowledgements: Thanks to Dave Bradford, US Forest Service, for encouraging me to write this article, Polly Oberosler, freelance writer and editor, for helping me turn my 62 sticky notes into a real story. And thank you to Joanna Sampson, author and historian, for sharing her knowledge and her computer. 